ISSN: 2224-0616

Int. J. Agril. Res. Innov. Tech. 10(2): 66-75, December 2020 Available online at https://ijarit.webs.com DOI: https://doi.org/10.3329/ijarit.v10i2.51579 https://www.banglajol.info/index.php/IJARIT

\title{
Effects of organophosphate insecticide, sumithion on histopathology of common carp (Cyprinus carpio) in the natural pond condition
}

\author{
M. Shira ${ }^{1}$, P. Chowdhury ${ }^{2 *}$, M.S. Rahman ${ }^{3}$, S.M. Haque ${ }^{4}$ and M. Shahjahan ${ }^{5}$
}

Received 02 September 2020, Revised 10 October 2020, Accepted 24 December 2020, Published online 31 December 2020

\begin{abstract}
A B S T R A C T
Sumithion is an organophosphorus insecticide, which is widely used in aquaculture ponds for eradication of aquatic insect (mainly tiger bug) prior to release of larvae. This study was conducted to evaluate the effects of an organophosphorus pesticide, sumithion on histoarchitecture of liver and kidney in common carp (Cyprinus carpio) during the period from July to December 2016. It was carried out with four treatments, each with two replications. i.e., ponds with no sumithion (To), with $0.025 \mathrm{ppm}$ sumithion (T1), 0.050 ppm sumithion (T2) and $0.100 \mathrm{ppm}$ sumithion (T3). The water quality parameters, such as $\mathrm{pH}$, dissolved oxygen, total alkalinity, free $\mathrm{CO}_{2}$, nitrate-nitrogen ( $\left.\mathrm{NO}_{3}-\mathrm{N}\right)$, phosphatephosphorus (PO4-P) were not affected by sub lethal doses of sumithion but the values were fluctuated significantly in most of the cases between the ponds throughout the study period. In case of histoarchitecture of liver and kidney, normal structure of liver and kidney cells were observed in the controlled and treated fish. Through the histological analysis of liver, small vacuole, enlarge lumen space of hepatopancreas and disrupted hepatopancreas were found in T1. Disrupted hepatopancreas, increasement intracellular space, regeneration of hepatic cell and hemorrhage were observed in T2. Moreover, enlarge lumen space of hepatopancreas, degenerated hepatic cell, disrupted hepatopancreas were observed in $\mathrm{T}_{3}$. After the histological analysis of kidney, degenerated renal corpuscle, enlargement of blood vessel, disrupted hematopoetic cell were observed in T1. Ruptured collecting duct, large vacuole, enlarge intracellular space were observed in T2. Furthermore, enlarge bowman's space, degenerated hematopoetic cell hemorrhage and ruptured distal tubule disrupted, enlarge intracellular space and necrosis were observed in T3. The present investigation sufficiently emphasizes that sumithion has adverse effects on the major organs like liver and kidney.
\end{abstract}

Keywords: Organophosphorus insecticide, Sumithion, Hematological parameter, Liver, Kidney, Common carp.

\footnotetext{
${ }^{I}$ Department of Fisheries Management, Bangladesh Agricultural University, Mymensingh, Bangladesh.

${ }^{2}$ Senior Scientific Officer, Bangladesh Fisheries Research Institute, Mymensingh, Bangladesh.

${ }^{3}$ Professor, Department of Fisheries Management, Bangladesh Agricultural University, Mymensingh, Bangladesh.

${ }^{4}$ Professor, Department of Fisheries Management, Bangladesh Agricultural University, Mymensingh, Bangladesh.

${ }^{5}$ Professor, Department of Fisheries Management, Bangladesh Agricultural University, Mymensingh, Bangladesh.

*Corresponding author’s email: nitoldhk@gmail.com (P. Chowdhury)
}

Cite this article as: Shira, M., Chowdhury, P., Rahman, M.S., Haque, S.M. and Shahjahan, M.2020.Effects of organophosphate insecticide, sumithion on histopathology of common carp (Cyprinus carpio) in the natural pond condition. Int. J. Agril. Res. Innov. Tech. 10(2): 66-75. https://doi.org/10.3329/ijarit.v10i2.51579

\section{Introduction}

Bangladesh is exclusively endowed with the diversity of very rich fresh and marine water fisheries resources comprising 260 indigenous species, 24 freshwater prawns, 475 marine fish species, 36 marine and brackish water shrimps and 16 exotic species (DoF, 2013). Fisheries contribute about $63 \%$ of animal protein in the daily diet of people of Bangladesh, $6 \%$ to the GNP and $11-14 \%$ of export earnings of the country species (DoF, 2014). Among the indigenous fish species, 12 have been categorized as critically endangered, 28 as endangered and 14 as vulnerable (IUCN Bangladesh, 2003). One of the major causes of this situation is the indiscriminate use of various insecticides and pesticides in the agricultural sectors. Pesticides have been mentioned as the contributor of gradual degradation of the aquatic ecosystem (Konar, 1975; Basak and Konar, 1976; 1977). Pesticides at high concentrations are known to 
reduce the survival, growth and reproduction of fish (Mckim et al., 1975) and produce many visible effects on fish (Johnson, 1968). Due to the residual effects of pesticides, important fish organs like gonads, kidney, liver, gills, stomach, brain and muscle are damaged. In Bangladesh, there is a rapid increase in the use of pesticide and chemical fertilizers for the growth of high yielding variety crops (HYVC). The insecticides and pesticides fall under four major groups viz. organochlorine, organophosphate, carbamate and pyrethroid.

Sumithion, [O, O Dimethyl O-(3-methyl-4nitrophenyl)] is an organophosphorus insecticide. It is effective against a wide range of pests, i.e. penetrating, chewing and sucking insect pests on cereals, cotton, orchard fruits, rice, vegetables, and forests. It may be used to control fly, mosquito, cockroach and also as residual contact spray for farms and public health program. In Bangladesh, sumithion is also widely used in aquaculture ponds for eradication of aquatic insect (mainly tiger bug) prior to release of larvae. Sumithion is considered somewhat toxic to fish (Thomson, 1989). At 96 hours after treatment (HAT), the $\mathrm{LC}_{50}$ value was $1.7 \mathrm{ppm}$ for brook trout and $3.8 \mathrm{ppm}$ for bluegill sunfish; moderately toxic to both warm water and cold water fish (Meister, 1994). At 96 HAT, the LC $_{50}$ value to various species of North American freshwater fish has also been reported as 2-12 $\mu \mathrm{g}$ $\mathrm{L}^{-1}$. The chronic toxicity of sumithion to fish is considered low (Murty, 1986). At 48 HAT, the $\mathrm{LC}_{50}$ values for carp ranged between $2.0 \mathrm{mg} \mathrm{L}^{-1}$ and $4.1 \mathrm{mg} \mathrm{L}^{-1}$ (Worthing and Walker, 1987). Fenitrothion (4.9 $\mathrm{mg} \mathrm{Kg}^{-1}$ ) persisted longer than four weeks in fish (Murty, 1986). In a study on the acute toxicity of sumithion to rainbow trout, embryos were found to be the least sensitive, the sac fry stage was intermediate, and fingerlings and adults were the most sensitive. The toxicity of sumithion to rainbow trout increased with increasing temperature.

The common carp, Cyprinus carpio is a highly palatable and preferred for culture due to its high growth rate and prolific breeding in confined water. The common carp, C. carpio is a native of the temperate regions of Asia especially of China (Gunther, 1868). At present, the common carp enjoys global distribution occurring in tropical as well as temperate regions acclimatized to a variety of habitats and extremes of environment. Two exotic varieties of common carp (scale carp and mirror carp) were introduced in mid nineteen fifties by fishery department. The fish have been well established in the waters of the valley, especially, the lentic habitats and over shadow at present almost all the indigenous species.
Every species has an immense power of biotic potential, and if the conditions are favorable the population may increase to the explosive level. But, it seldom happens, because from the beginning of gametogenesis the attainment of maturity, there are a number of factors responsible for untimely death of embryos, juveniles and adults even before they start reproducing. Many commercial and productive fish species are adversely affected in modern times, due to severe, fast and undesirable changes detrimental to their surroundings, survival and viability. Fish populations are often subject to sudden and large scale mortalities. This happens due to unusual natural causes, and such mortalities are beyond remedy. Then there are equally significant mortalities of fish population, which stem from causes for which humanity is responsible. Near large centers of urban agglomerations and in proximity of mines, mills, industries and the like changes are brought in the chemical, physical and biological qualities of water so much as to cause mass killing of fish life. Considering the toxic effects of sumithion on fish and other aquatic organisms discussed above, it is essential to know the extent of damage in aquatic environment caused by pesticides and to find out the concentrations below which aquatic lives live in safe environment. Fish exposed to pesticides present in the ecosystem which receives it from agriculture runoff and industrial wastes, exhibited a variety of reproductive problems such as reducing number of sperm, abnormal gamete, reducing fecundity (Patyna et al., 1999), sex reversal (Mills and Chichester, 2005), low hatching rate and survivability (Rahman et al., 2002). Hence, it is thought to be worthwhile to conduct a research on the effects of sumithion on histoarchitecture of liver and kidney of common carp.

\section{Materials and Methods}

\section{Selection of test fish species}

Healthy and active specimens of common carp, $C$. carpio were procured from a fish farm named 'Shagor Fish Farm' located at Digharkanda, Mymensingh. The length and weight of fishes ranged from 3 to $4 \mathrm{~cm}$ and 5 to $8 \mathrm{~g}$, respectively. The fishes were released in 8 ponds each having an area of 2 decimal situated at the northern side of the faculty of fisheries, BAU, Mymensingh. The collected fish were reared in the ponds. During this period, the fish were fed normal food daily.

\section{Selection of pesticide}

In Bangladesh, many types of pesticides are used every year in crop fields to control insects and to increase production. Among them, Sumithion 50 EC is most common which belongs to the organophosphorous group. To conduct this experiment, sumithion $50 \mathrm{EC}$ was collected from a retail pesticide shop of Mymensingh city. 


\section{Experimental design}

The experimental layout has been given in the table below:

2.1. Layout of the experiment.

\begin{tabular}{|c|c|c|c|}
\hline $\begin{array}{c}\text { Treatments } \\
\text { Teplications }\end{array}$ & $\begin{array}{c}\text { Concentration of } \\
\text { Sumithion } \\
\text { (Control) }\end{array}$ & No sumithion & $\begin{array}{c}\text { Fish sp. for test, its length \& weight } \\
\text { and no. per decimal of pond }\end{array}$ \\
\hline $\mathrm{T}_{1}$ & 2 (2 ponds) & $\begin{array}{c}\text { Cyprinus carpio } \\
\text { to } 4 \mathrm{~cm}, 5 \text { to } 7 \mathrm{~g}, 30 \text { fish/decimal }\end{array}$ \\
\hline $\mathrm{T}_{2}$ & 2 Donds) & $0.025 \mathrm{mg} \mathrm{L}^{-1}$ & Do \\
\hline $\mathrm{T}_{3}$ & 2 (2 ponds) & $0.050 \mathrm{mg} \mathrm{L}^{-1}$ & Do \\
\hline
\end{tabular}

\section{Application of sumithion into pond water}

The insecticide, sumithion was applied in pond water according to water volume and calculated amount of sumithion have been shown in the table below:

Table 2.2.Water volume of ponds, amount of sumithion used and concentration of sumithion in pond water.

\begin{tabular}{|c|c|c|} 
Treatments & Pond No. & $\begin{array}{c}\text { Total amount of } \\
\text { Sumithion applied } \\
\text { in pond }\end{array}$ \\
\hline \multirow{2}{*}{$\mathrm{T}_{1}$} & $\mathrm{P} 3$ & About $1.00 \mathrm{ml}$ \\
\cline { 2 - 3 } & $\mathrm{P} 5$ & $1.00 \mathrm{ml}$ \\
\hline \multirow{2}{*}{$\mathrm{T}_{2}$} & $\mathrm{P} 2$ & $2.32 \mathrm{ml}$ \\
\hline \multirow{2}{*}{$\mathrm{T}_{3}$} & $\mathrm{P} 6$ & $2.40 \mathrm{ml}$ \\
\hline & $\mathrm{P} 1$ & $4.04 \mathrm{ml}$ \\
\hline & $\mathrm{P} 4$ & $4.90 \mathrm{ml}$ \\
\hline
\end{tabular}

Examination of the effect of insecticide sumithion on liver and kidney of common carp (Cyprinus carpio)

\section{Collection of organs}

The fish species from both control and treated ponds were dissected at an interval of $0,7,15$ and 30 days and organs like liver and kidney were carefully collected by dissection and immediately kept in vials filled with 10\% formalin and kept at room temperature for preservation.

\section{Histological study of organs}

\section{Dehydration}

The fixed samples were kept into the cassette and passed through a graded alcohol series. The samples that kept in $10 \%$ formalin fixative were started dehydration from $70 \%$ ethyl alcohol and proceed on up to $100 \%$ ethyl alcohol (Table 2.3.)

Table 2.3.The dehydration schedule.

\begin{tabular}{|c|c|c|}
\hline Sl. No. & Solution & Time \\
\hline 1 & $70 \%$ Ethyl alcohol & 12 hours \\
\hline 2 & $80 \%$ Ethyl alcohol & 12 hours \\
\hline 3 & $90 \%$ Ethyl alcohol & 12 hours \\
\hline 4 & $95 \%$ Ethyl alcohol & 6 hours \\
\hline 5 & $100 \%$ Ethyl alcohol & 4 hours \\
\hline 6 & $100 \%$ Ethyl alcohol & 4 hours \\
\hline
\end{tabular}

\section{Clearing}

Dehydrated samples were cleared by using chloroform twice successively for 2-3 hours to remove traces of alcohol in order to have

\begin{tabular}{|c|c|}
$\begin{array}{c}\text { Volume of water } \\
\text { of pond } \\
\left(\mathrm{m}^{3} \text { or liter }\right)\end{array}$ & $\begin{array}{c}\text { Concentration of } \\
\text { Sumithion } \\
\left(\mathrm{mg} \mathrm{L}^{-1}\right) \text { in pond water }\end{array}$ \\
\hline 37.37 or 37370 & 0.025 \\
\hline 41.23 or 41230 & 0.025 \\
46.45 or 46450 & 0.050 \\
47.98 or 47980 & 0.050 \\
40.39 or 40390 & 0.100 \\
49.01 or 49010 & 0.100 \\
\hline
\end{tabular}

consistent paraffin blocks. The process is mentioned in Table 2.4

Table 2.4.The clearing schedule.

\begin{tabular}{|c|c|c|}
\hline Sl. No. & Solution & Time \\
\hline 1 & Chloroform & 1.5 hours \\
\hline 2 & Chloroform & 1.5 hours \\
\hline
\end{tabular}

\section{Infiltration}

The cassettes holding the samples were marked previously in accordance with the number of samples. From chloroform, the samples were taken out from the cassette and placed in paraffin sequentially in incubator (EL-450 B) following the steps shown below in Table 2.5 .

Table 2.5.The infiltration schedule.

\begin{tabular}{|c|c|c|}
\hline Sl. No. & Solution & Time \\
\hline 1 & Paraffin & 40 minutes \\
\hline 2 & Paraffin & 40 minutes \\
\hline
\end{tabular}

\section{Embedding}

After infiltration, the cassettes were taken out one by one, being opened, settling the sample in the middle of a small paper-box previously marked as in the cassette and filled with melted paraffin from wax dispenser. Then the paperboxes were allowed to cool in room temperature. Thus the embedded blocks containing the sample were formed which allowed smooth sectioning.

Trimming

Trimming is a process in which the undesirable 
wax layers of the embedded blocks are trimmed by knife to obtain suitable blocks. Trimming allowed easy sectioning. Trimming was done by using microtome blades. In this step both side trimming and surface trimming were conducted.

\section{Sectioning}

Paraffin embedded blocks was cut by microtome knife in microtome machine (KEDEE KD-3358, China) at $6 \mu \mathrm{m}$ thick size. The sections were placed on lower part of a glass slide previously tagged and filled with water drops. The sections were kept overnight at room temperature for proper drying.

\section{Staining}

Staining is a process by which samples are stained with various dyes and staining materials so that their components become visible under microscope. Staining was done following the schedule in Table 2.6.

Table 2.6.The staining schedule.

\begin{tabular}{|c|c|c|c|}
\hline Sl. No. & Solution & Time & Process \\
\hline 1. & Xylene & 10 minutes & Clearing \\
\hline 2. & Xylene & 10 minutes & Clearing $(1-3)$ \\
\hline 3. & Xylene & 10 minutes & Clearing $(1-3)$ \\
\hline 4. & $100 \%$ Ethyl alcohol & 5 minutes & \\
\hline 5. & $100 \%$ Ethyl alcohol & 5 minutes & Rehydration $(4-8)$ \\
\hline 6. & $90 \%$ Ethyl alcohol & 3 minutes & Rehydration $(4-8)$ \\
\hline 7. & $80 \%$ Ethyl alcohol & 3 minutes & Rehydration $(4-8)$ \\
\hline 8. & $70 \%$ Ethyl alcohol & 3 minutes & Rehydration $(4-8)$ \\
\hline 9. & $50 \%$ Ethyl alcohol & 2 minutes & \\
\hline 10. & Distilled water & 15 dips & Staining $(9-15)$ \\
\hline 11. & Hematoxylene $($ Harris $)$ & 3 minutes & Staining $(9-15)$ \\
\hline 12. & Wash in tap water & 15 minutes & Staining $(9-15)$ \\
\hline 13. & $50 \%$ Ethyl alcohol & $10-15$ dips & Staining $(9-15)$ \\
\hline 14. & $95 \%$ Ethyl alcohol & 30 seconds & Staining $(9-15)$ \\
\hline 15. & Eosin Y & 1 minutes & Staining $(9-15)$ \\
\hline 16. & $95 \%$ Ethyl alcohol & 2 minutes & \\
\hline 17. & $100 \%$ Ethyl alcohol & 1 minutes & Dehydration $(16-19)$ \\
\hline 18. & $100 \%$ Ethyl alcohol & 3 minutes & Dehydration $(16-19)$ \\
\hline 19. & $100 \%$ Ethyl alcohol & 1 minutes & Dehydration $(16-19)$ \\
\hline 20. & Xylene & 20 minutes & Clearing \\
\hline 21. & Xylene & 20 minutes & Clearing $(20-21)$ \\
\hline 22. & Drying at room temperature & Over night & Drying \\
\hline
\end{tabular}

\section{Mounting}

In this process the tissue sections on the slides were covered with a cover slip. DPX was used for mounting as a mounting agent. A drop of DPX was put on each slide followed by attachment of cover slip $(22 \mathrm{~mm} \times 22 \mathrm{~mm})$. After mounting the slides were put for several hours in room temperature.

\section{Microscopic view of the tissue sections}

The mounted slides were observed under a microscope (OLYMPUS microscope; Model: CX21, Japan) which was connected to computer with OPTIKA MB3 Digital camera (3.14 Mega pixel). By the help of this mechanism, numerous photographs were taken at different magnifications. For preparing histological slides only steps and time is sufficient.

\section{Statistical analysis}

Values are expressed as means \pm standard deviation (SD). Data were analyzed by one-way

analysis of variance (ANOVA) followed by Tukey's post hoc test to assess statistically significant differences among different treatments. Statistical significance was set at $P<0.05$. Statistical analyses were performed using PASW Statistics 18.0 software (IBM SPSS Statistics, IBM, Chicago, USA).

\section{Results}

\section{Effects of sumithion on histoarchitecture in kidney}

Kidney tubules, renal corpuscle, hematopoietic cell, blood vessel were normal and systematically arranged in the control treatment (Fig. 1A, 2A and $3 \mathrm{~A}$ ). Sumithion exposed kidney sections showed vacuolation, necrosis, cellular degeneration, enlarge blood vessel, hemorrhage and rupture of kidney tubules. Kidney tissue of Cyprinus carpio exposed to $0.025 \mathrm{ppm}$ sumithion under the treatment $\mathrm{T}_{1}$ showed degenerated renal corpuscle on 7 days of exposure (Fig. 1B). Ruptured collecting duct was 
found at the dosage of 0.050 ppm belong to $\mathrm{T}_{2}$ treatment (Fig. 1C) and degenerated hematopoietic cell, enlarge blood vessel were observed at the dosage of 0.100 ppm (Fig. 1D) on 7 days of exposure. Expand blood vessel and disrupted hematopoietic cell were found at the dosage of $0.025 \mathrm{ppm}$ on 15 days of exposure (Fig. 2B). Disrupted collecting duct was found at the dosage of $0.050 \mathrm{ppm}$ (Fig. 2C) and expand bowman's space, degeneration of hematopoietic cell were also recorded at the dosage of 0.100 ppm (Fig. 2D) on 15 days of exposure. Vaculotaion, necrosis, disrupted hematopoietic tissue were observed at the dosage of 0.025 under $\mathrm{T}_{1}$ treatment on 30 days of exposure (Fig. $3 \mathrm{~B}$ ). Enlargement of intracellular space was recorded at the dosage of $0.050 \mathrm{ppm}$ under $\mathrm{T}_{2}$ treatment on 30 days of exposure (Fig. $3 \mathrm{C}$ ). Ruptured hematopoietic cell, increase intracellular space and hemorrhage were also found at the dosage of 0.100 ppm belong to $\mathrm{T}_{3}$ treatment on 30 days of exposure (Fig. 3D).
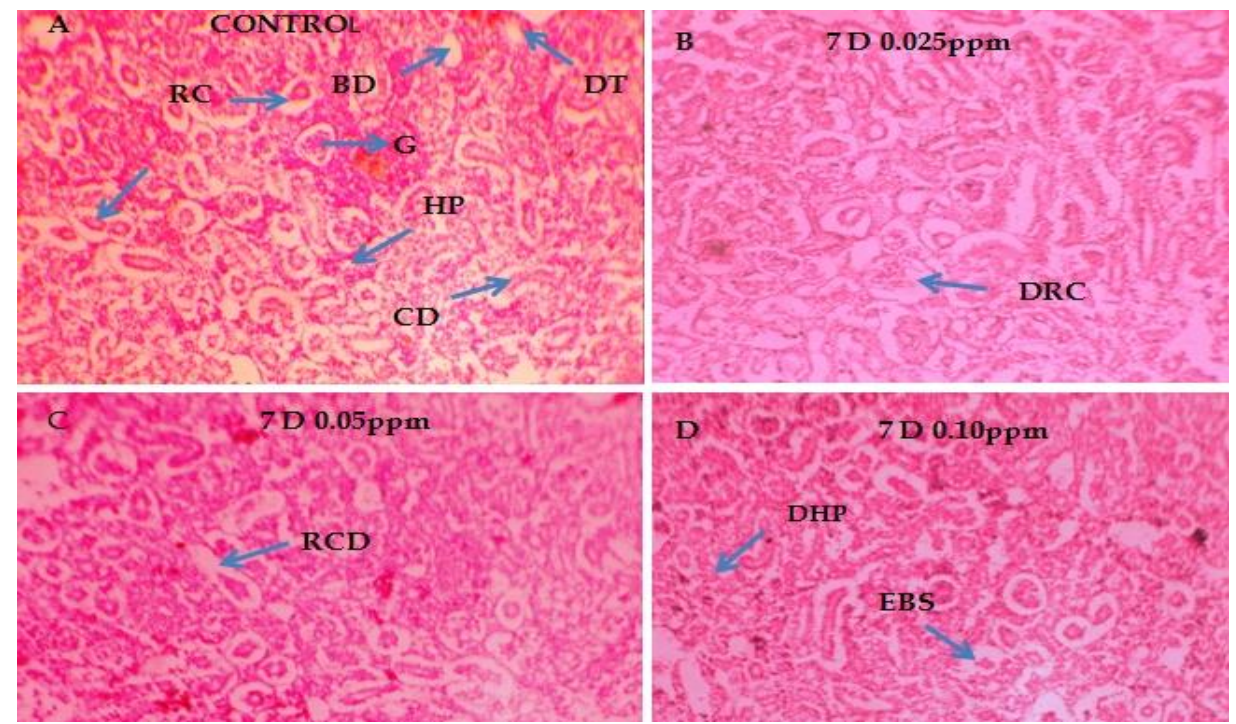

Fig. 1. Histological changes in kidney ( $\mathrm{H}$ and $\mathrm{E}$ stained, $\mathrm{X} 100)$ exposed to sumithion: (A) Control ( $\left.\mathrm{T}_{\mathrm{O}}\right)$; (B) $0.025 \mathrm{ppm}\left(\mathrm{T}_{1}\right)$; (C) $0.050 \mathrm{ppm}\left(\mathrm{T}_{2}\right)$ and (D) $0.100 \mathrm{ppm}\left(\mathrm{T}_{3}\right)$ at 7 days of exposure. Arrowheads are indicating- RC (renal corpuscle), PT (proximal tubule), DT (distal tubule), CD (collecting duct), G (glomerulus), HP (hematopoietic cell), BV (blood vessel), RCD (ruptured collecting duct), DRC (disrupted renal corpuscle), DHP (degenerated hematopoietic cell) and EBS (enlargement of bowman's space).
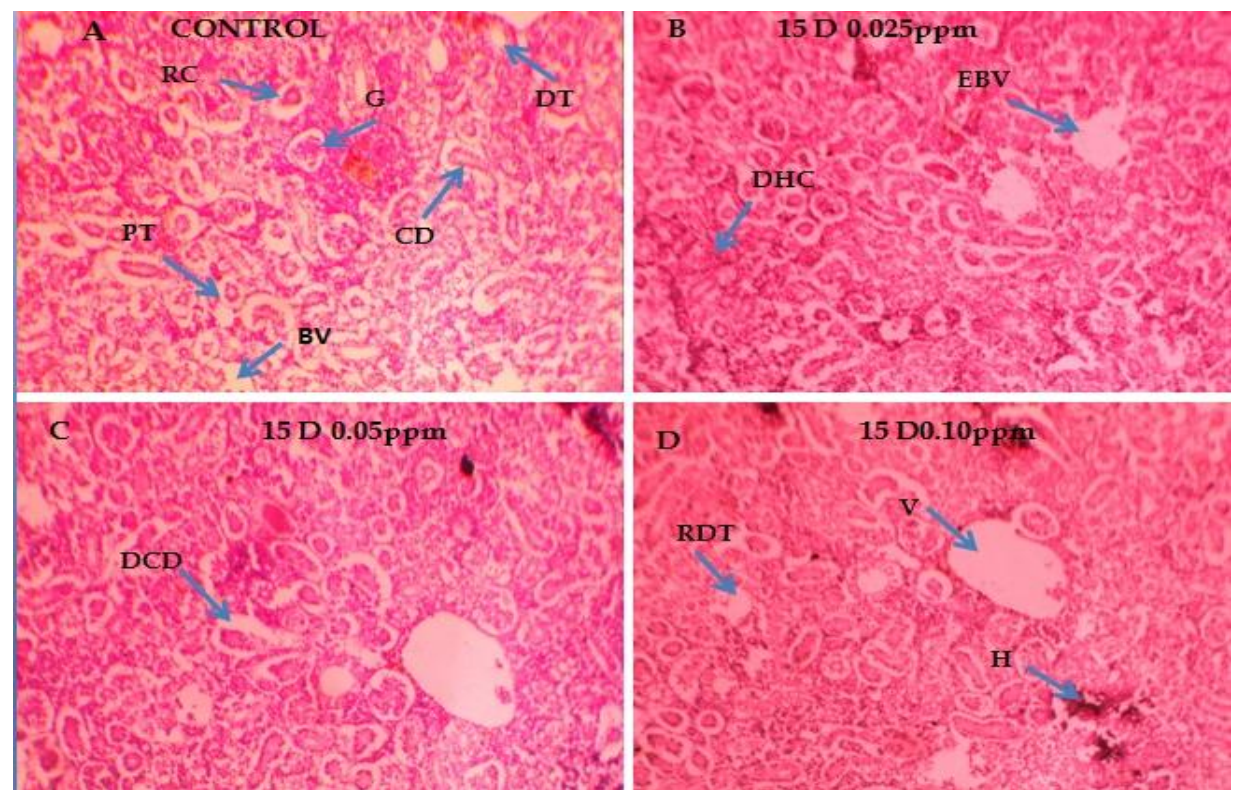

Fig. 2. Histological changes in kidney ( $\mathrm{H}$ and E stained, $\mathrm{X100}$ ) exposed to sumithion: (A) Control ( $\mathrm{T}_{0}$ ); (B) $0.025 \mathrm{ppm}\left(\mathrm{T}_{1}\right)$; (C) $0.05 \mathrm{ppm}\left(\mathrm{T}_{2}\right)$ and (D) $0.1 \mathrm{ppm}\left(\mathrm{T}_{3}\right)$ at 15 days of exposure. Arrowheads are indicating- RC (renal corpuscle), DT (distal tubule), CD (collecting duct), G (glomerulus), BV $\backslash(\mathrm{blood}$ vessel) DHC (degenerated hematopoietic Cell) EBV (expand blood vessel), DCD (disrupted collecting duct), RDT (ruptured distal tubule), V (vacuole) and H (hemorrhage). 

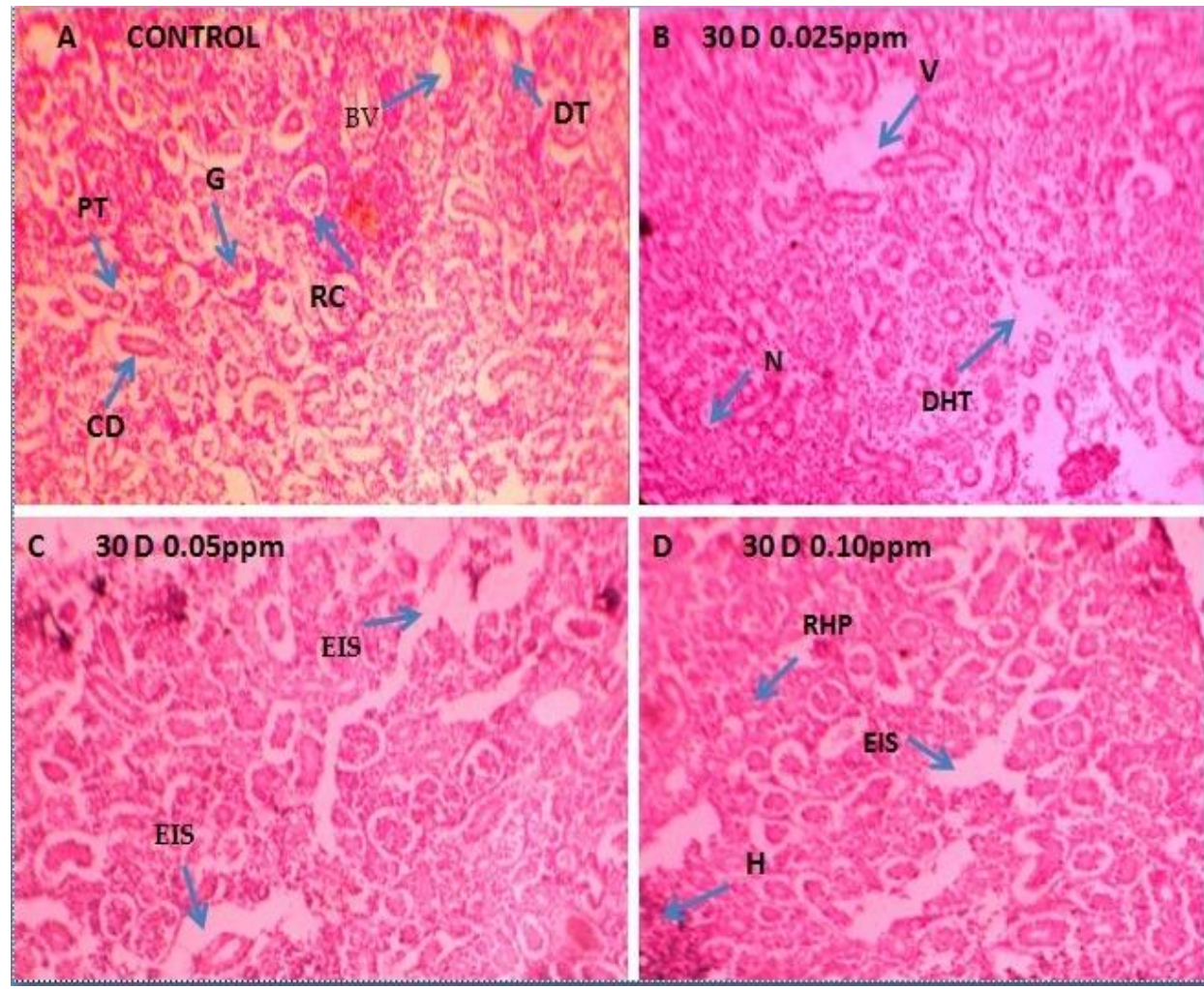

Fig. 3. Histological changes in kidney (H and E stained, $\mathrm{X} 100)$ exposed to sumithion: (A) Control $\left(\mathrm{T}_{0}\right)$; (B) $0.025 \mathrm{ppm}\left(\mathrm{T}_{1}\right)$; (C) $0.050 \mathrm{ppm}\left(\mathrm{T}_{2}\right)$ and (D) $0.100 \mathrm{ppm}\left(\mathrm{T}_{3}\right)$ at 30 days of exposure. Arrowheads are indicating- RC (renal corpuscle), G (glomerulus), PT (proximal tubule), DT (distal tubule), CD (collecting duct), BV (blood vessel), DHP (degenerated hematopoietic tissue), V (vacuole), N (necrosis), EIS (enlarge intracellular space), RHP (ruptured hematopoietic cell) and H (hemorrhage).

\section{Effects of sumithion on histoarchitecture of liver}

In the concerned study period, the histoarchitecture of liver of common carp was observed through histological study. The hepatocytes, hepatopancreas blood vessel and other cells of the liver in control $\left(\mathrm{T}_{0}\right)$ were normal and systematically arranged (Fig. 4A, 5A, 6A). When carp exposed to sumithion, liver sections showed small and large vacuolation, hemorrhage, necrosis, hepatic cell degeneration, ruptured hepatopancreas, increasement of intracellular space, expand blood vessel, enlarge hepatic lumen, hypertrophy of hepatocytes and large vacuolation into hepatopancreas. Liver tissue of common carp exposed to $0.025 \mathrm{ppm}$ (T1) sumithion showed small vacuolation (Fig.4B), disrupted hepatopancreas (Fig. 4C) in treatment $\mathrm{T}_{2}$ (0.050 ppm) and enlargement of hepatopancreas lumen (Fig. $4 \mathrm{D}$ ) in treatment $\mathrm{T}_{3}$ (o.100 ppm) on 7 days exposure . Enlarge lumen space and hemorrhage (Fig. ${ }_{5} \mathrm{~B}$ ) in treatment $\mathrm{T}_{1}$, disrupted hepatopancreas (Fig. $5 \mathrm{C}$ ) in treatment $\mathrm{T}_{2}$ and degenerated hepatic cell, enlarge hepatopancreas lumen(Fig. $5 \mathrm{D}$ ) in treatment $\mathrm{T}_{3}$ on 15 days exposure. Disrupted hepatopancreas (Fig. 6B) was found in treatment $\mathrm{T}_{1}$, increase intracellular space, disrupted hepatopancreas, degenerated hepatic cell (Fig. 6C) in treatment $\mathrm{T}_{2}$, and expand blood vessel, vacuolation of hepatopancreas lumen (Fig. 6D) in treatment $\mathrm{T}_{3}$ on 30 days exposure. 

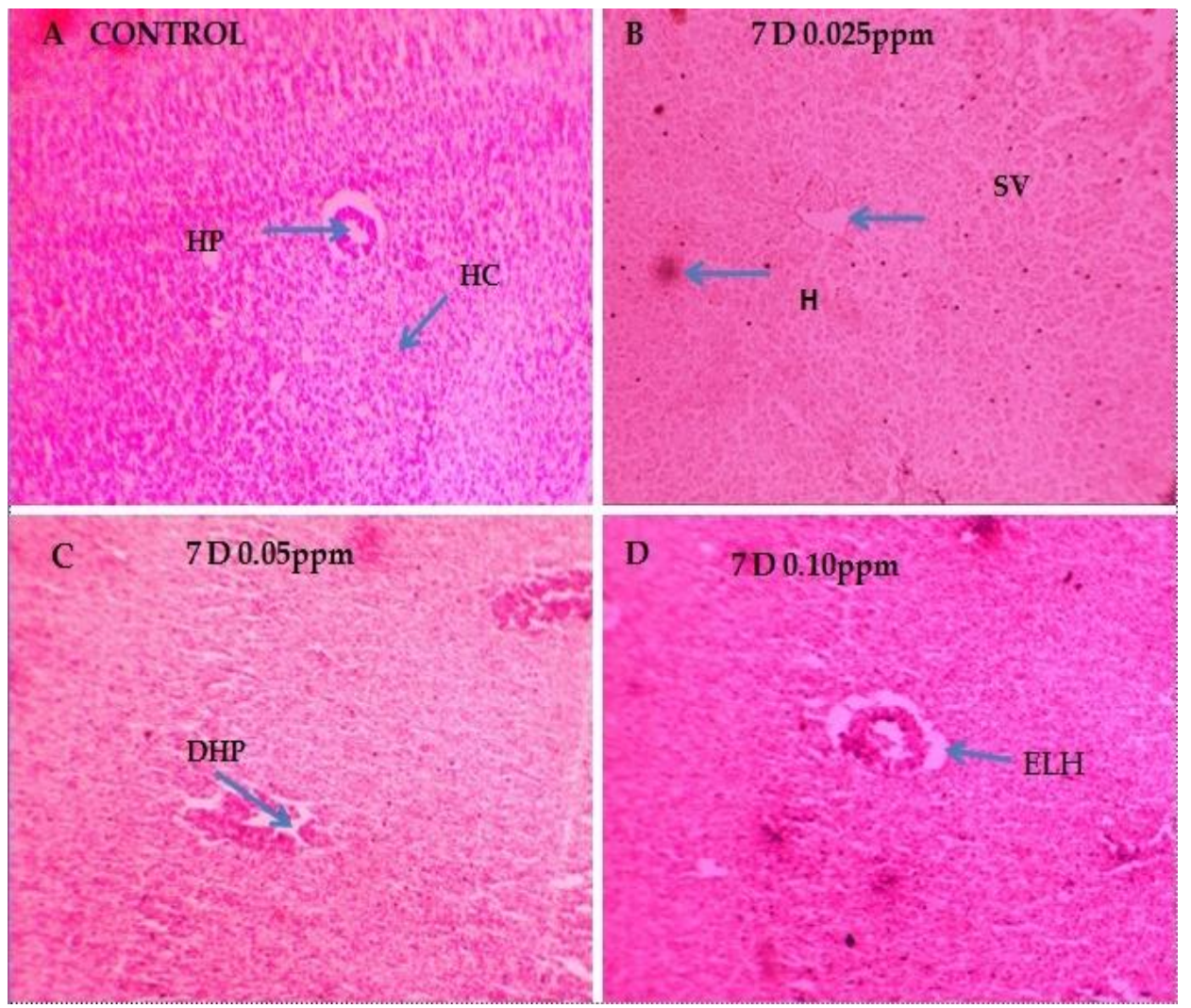

Fig. 4. Histological changes in Liver ( $\mathrm{H}$ and E stained, X100) exposed to sumithion: (A) Control ( $\mathrm{T}_{0}$ ); (B) $0.025 \mathrm{ppm}\left(\mathrm{T}_{1}\right)$; (C) $0.050 \mathrm{ppm}\left(\mathrm{T}_{2}\right)$ and (D) $0.100 \mathrm{ppm}\left(\mathrm{T}_{3}\right)$ at 7 days of exposure. Arrowheads are indicating- HP (hepatopancreas), HC (hepatic cell), SV (small vacuole), H (hemorrhage), DHP (disruptured hepatopancreas), and ELH (enlarge lumen of hepatopancreas).
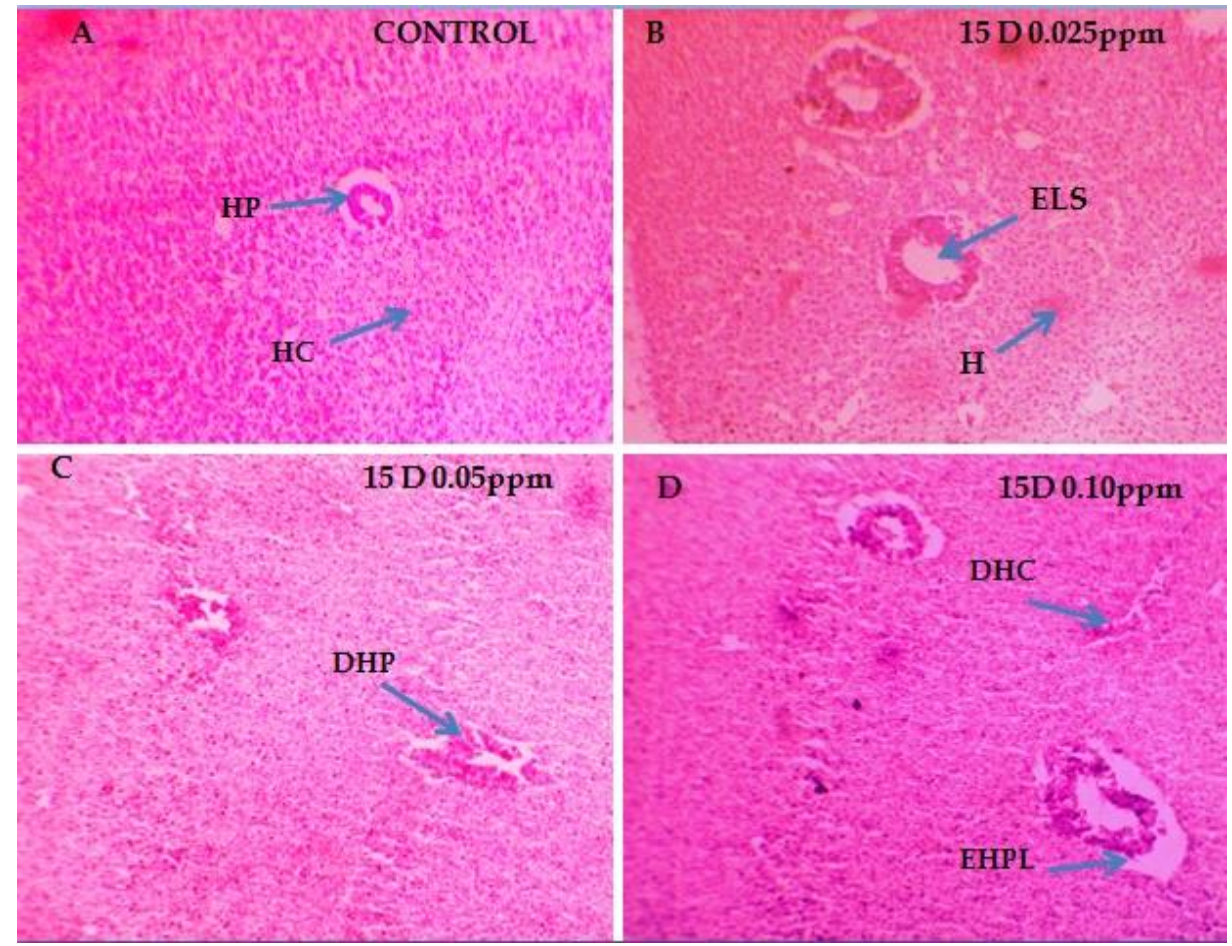

Fig. 5. Histological changes in Liver ( $\mathrm{H}$ and $\mathrm{E}$ stained, $\mathrm{X} 100)$ exposed to sumithion: (A) Control ( $\mathrm{T}_{0}$ ); (B) $0.025 \mathrm{ppm}\left(\mathrm{T}_{1}\right)$; (C) $0.050 \mathrm{ppm}\left(\mathrm{T}_{2}\right)$ and (D) $0.100 \mathrm{ppm}\left(\mathrm{T}_{3}\right)$ at 15 days of exposure. Arrowheads are indicating- HP (hepatopancreas), HC (hepatic cell), ELS (enlarge lumen space), H (hemorrhage), DHP (disrupted hepatopancreas), DHC (degenerated hepatic cell), and EHPL (enlarge hepatopancreas lumen). 

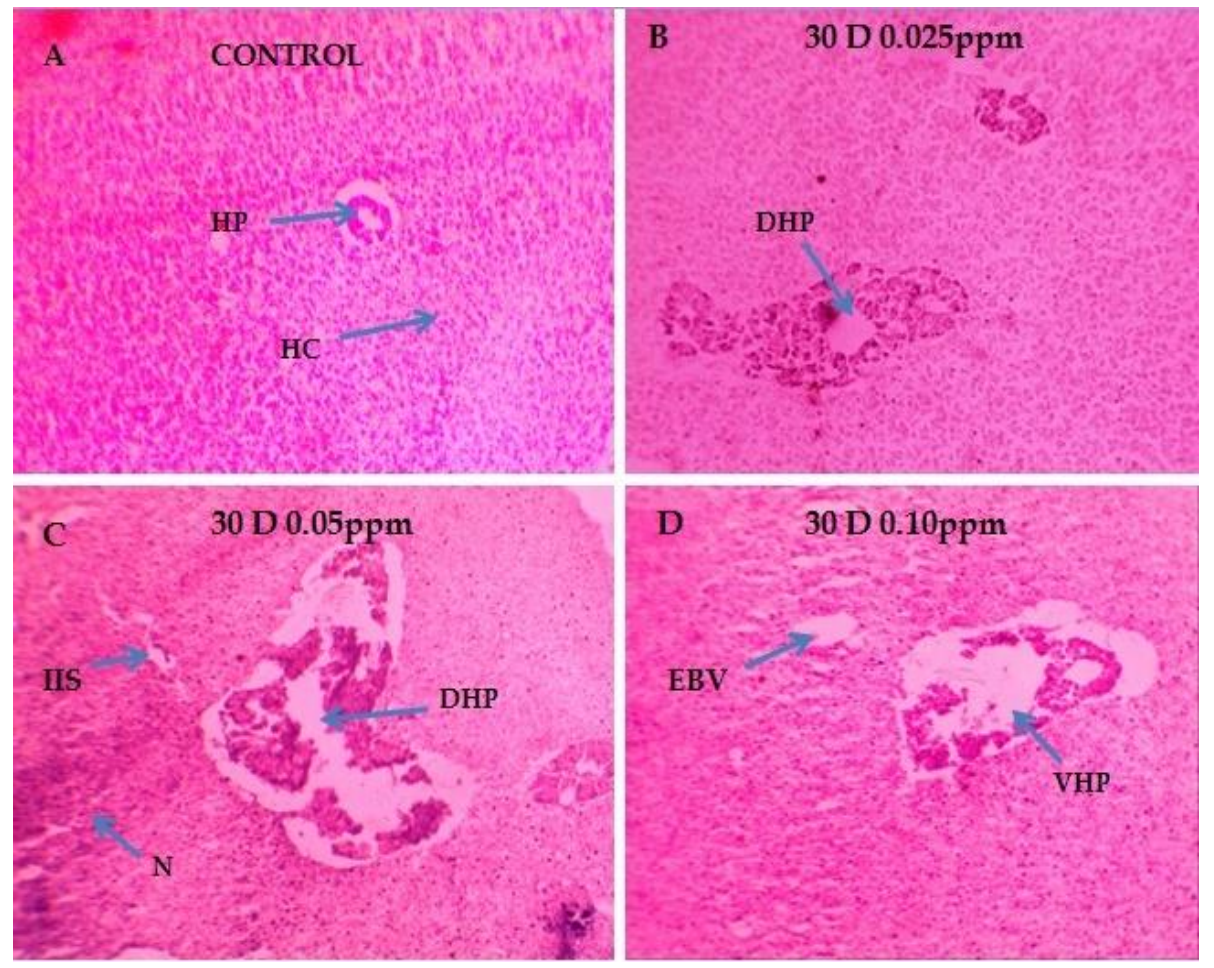

Fig. 6. Histological changes in Liver ( $\mathrm{H}$ and $\mathrm{E}$ stained, $\mathrm{X100}$ ) exposed to sumithion: (A) Control $\left(\mathrm{T}_{\mathrm{o}}\right.$ ); (B) $0.025 \mathrm{ppm}\left(\mathrm{T}_{1}\right)$; (C) $0.050 \mathrm{ppm}\left(\mathrm{T}_{2}\right)$ and (D) $0.100 \mathrm{ppm}\left(\mathrm{T}_{3}\right)$ at 30 days of exposure. Arrowheads are indicating- HP (hepatopancreas), HC (hepatic cell), DHP (disrupted hepatopancreas), DHP (degenerated hepatopancreas), N (necrosis), IIS (increase intracellular space) EBV (expand blood vessel) and VHC (vacuolation in hepatopancreas).

\section{Discussion}

A number of changes have been documented in this present study in water quality parameters, plankton population and the histoarchitecture of liver and kidney in the concerned species Cyprinus carpio, which are discussed below:

In the current study period, histology of kidney of test species Cyprinus carpio was also conducted after definite exposure of sumithion. The control kidney $\left(\mathrm{T}_{0}\right)$ of test species (Cyprinus carpio) composed of mass hepatopoetic cell, undamaged renal corpuscle with glomeruli and bowman's space, entire collecting duct and kidney tubule including distal and proximal tubule as well as undamaged blood vessel. In the present study, the selected common carp species were exposed to sumithion at desired concentrations (o, 0.025, 0.050 and $0.100 \mathrm{ppm}$ ) for an exposure period of $7,15,30$ days. Here through the histological analysis of kidney degenerated renal corpuscle, ruptured collecting duct and enlarged bowman's space, degenerated hematopeotic cell were observed at $0.025,0.050$ and $0.100 \mathrm{ppm}$ for an exposure period of 7 days. While enlargement of blood vessel, large vacuole and hemorrhage and ruptured distal tubule disrupted were noticed at $0.025,0.050$ and $0.100 \mathrm{ppm}$ for an exposure period of 15 days. Furthermore, disrupted hematopoetic cell, enlarged intracellular space and necrosis was found at $0.025,0.050$ and $0.100 \mathrm{ppm}$ for an exposure of 30 days.

Sharkar (2016) exposed Tengra, Mystus tengara to six different concentrations of cypermethrin 10 $\mathrm{EC}$, which were $0.1 \mathrm{ppm}, 0.2 \mathrm{ppm}, 0.4 \mathrm{ppm}, 0.8$ ppm, $1.6 \mathrm{ppm}$, and $3.2 \mathrm{ppm}$ including a control and observed vacuolation, necrosis and ruptured kidney tubules, cellular degeneration and karyolysis which are also more or less similar to the findings of present study. Similar histological changes were also reported by Konar (1975), degenerated kidney tubules in carp (Labeo rohita) and catfish (Heteropneus tesfossilis) when exposed to 200 and $210 \mathrm{ppm}$ of phosphamidon for 168 hours. The results of the present study are similar to the findings of Rahman et al. (2002). They reported necrosis, pyknosis, hemorrhages, vacuolation, degeneration of kidney tubules and hematopoetic cells on Anabas testudineus, Channa punctatus and Barbodes gonionotus at $3.75 \mathrm{ppm}, 2.26 \mathrm{ppm}$ and $2.26 \mathrm{ppm}$, of diazinon $60 \mathrm{EC}$, respectively for 7 days. Nannu (2014) investigated the sub lethal effects of an organophosphorous pesticide, kinalux 25 EC on kidney of Nile tilapia, Oreochromis niloticus and observed that highly degenerated kidney tubules and hematopoietic tissues, degeneration of renal corpuscles, 
vacuolization, and necrosis of treated fishes, which are also similar to the findings of present study. Butchiram et al. (2009) reported necrosis, swelling of renal tubules, cellular hypertrophy and granular cytoplasm of kidney of Channa punctatus exposed to alachlor for a period of 10 days, which are different to the findings of present study.

Histopathological studies are beneficial tools to assess the effects of toxicants on fish (Pimpao et al., 2007). In the current study period, histology of liver of concerned species was conducted after definite exposure of sumithion. The control liver is composed of a mass of large hexagonal hepatic cells with cord-like formations. Each cell contains centrally located distinct vesicular nuclei. Cytoplasm contains granular deposits, sometimes with mild vacuolation. Large number of blood vessels and intercellular bile canaliculi are scattered among the hepatic cords. Hepatopancreatic cells were seen to surround the hepatic portal vein as darkly stained large cells. In the present study, the selected common carp species were exposed to sumithion at desired concentrations (o, 0.025, 0.050 and $0.100 \mathrm{ppm})$ for an exposure period of $7,15,30$ days. Here through the histological analysis of liver disrupted hepatopancreas and enlargement of hepatopancreas lumen were observed at 0.050 and $0.100 \mathrm{ppm}$ for an exposure period of 7 days. While enlargement of lumen space and disrupted hexagonal hepatic cell were noticed at 0.025 and $0.100 \mathrm{ppm}$ for an exposure period of 15 days. Furthermore, incensement of intracellular space and necrosis was found at $0.050 \mathrm{ppm}$, enlargement of blood vessel and large vacuolation into hepatopancreatic cell at 0.01 ppm for an exposure of 30 days. Salam ( 2014) exposed Cyprinus carpio to 3 different concentrations (o.8, 1.6, 3.20 ppm) and observed hypertrophy of hepatocytes, mild to severe necrosis, blood spilling and minor vacuolation in liver at higher concentration of sumithion, which are different to the findings of the present study. Monir et al. (2015) exposed Pangasianodon hypophthalmus to five acute concentrations (0.00 ml L-1, $0.025 \mathrm{ml} \mathrm{L}^{-1}$, $0.075 \mathrm{ml} \mathrm{L}^{-1}, 0.50 \mathrm{ml}$ $\mathrm{L}^{-1}, 0.10 \mathrm{ml} \mathrm{L}^{-1}$ of cypermethrin and observed cloudy swelling, focal necrosis and hypertrophy of hepatocytes, degeneration of hepatocytes and cytoplasmic, extensive vacuolation of hepatocytes and pyknoticnucli which are similar to the findings of present study. Shastry and Sharma (1979) exposed Channa punctatus to a sublethal concentration (0.01 $\left.\mathrm{mg} \mathrm{L}^{-1}\right)$ of endrin and observed hypertrophy of hepatic cells and liver cord disarray, vacuolation of cytoplasm and necrosis, rupture of hepatic cell membrane and necrotic centrolobular area which is more or less similar to the findings of the present study.
Similar histological changes were also reported by Kabir and Begum (1978) are cytoplasmic degeneration, pyknotic nuclei in liver tissues; vacuolation in hepatic cells and rupture of blood vessels; degenerative hepatic cells and necrotic nuclei when Heteropneutes fossilis was exposed for 25 days to 5,10 and $20 \mathrm{ppm}$ diazinon, respectively. Moitra and Sadhu (1982) reported vacuolation, necrosis and swollen cell of hepatic tissue when Channa striatus was exposed to 1.0, 5.0 and 10.0 ppm of phosphamidon for 10 days, which are different to the present study. The result of the present experiment coincided with the findings such as degeneration of cytoplasm in hepatocytes, atrophy, formation of vacuoles, rupture in blood vessels and disposition of hepatic cords in the liver as reported by Butchiram et al. (2009) due to the exposure of alachlor on Channa punctatus for 10 days. Elezaby et al. (2001) studied the effect of malathion on the fish Oreochromis niloticus and observed necrosis and lipidosis in the liver, which are different to the findings of present study.

From the above discussion, we can say that sumithion $50 \mathrm{EC}$ is significantly toxic to the Cyprinus carpio and other freshwater fishes. The little amount of this pesticide can causes histological changes in liver and kidney of common carp. So, the pesticide should not be used indiscriminately and the use of pesticide in agricultural land and aquaculture ponds, must be carefully evaluated, observed and controlled.

\section{References}

Basak, P.K. and Konar, S.K. 1976. Pollution of water by pesticides and protection of fishes: Parathion. Proc. Nat. Acad. Sci. India. 46: 382-392.

Basak, P.K. and Konar, S.K. 1977. Estimation of safe concentration of insecticides, a new method tested on DDT and BHC. J. Inl. Fish. Soc. India. 9: 9-29.

Butchiram, M.S., Tilak, K.S. and Raju, P.W. 2009. Studies on histopathological changes in the gill, liver and kidney of Channa punctatus (Bloch) exposed to Alachlor. $J$. Environ. Biol. 30(2): 303-330.

DoF. 2013. Jatio Matsha Saptaho. Department of Fisheries, Ministry of Fisheries and Livestock, Bangladesh. P. 43.

DoF. 2014. Jatio Matsha Saptaho. Department of Fisheries, Ministry of Fisheries and Livestock, Bangladesh. P. 22.

Elezaby, M.M., El-Serafy, S., Heckmann, R., Sharf, K.H., Eldeen, M.M. and Seddek. 2001. Effect of some toxicants on the fresh water fish Oreochromis niloticus. J. Egypt Ger. Soc. Zool. 36: 407-434.

Gunther, A. 1868. Cat. Fish. Brit. Mus. London. 7: 25 . 
IUCN Bangladesh. 2003. Red Book of Threatened Fishes of Bangladesh. IUCN-The World Conservation Union. P. 56.

Johnson, D.W. 1968. Pesticides and Fishes: a review of selected literature. Trans. Am. Fish. Soc. 97: 398-424. https://doi.org/10.1577/15488659(1968)97[398:PAFROS]2.0.CO;2

Kabir, S.M.H. and Begum, R. 1978. Toxicity of three organophosphorus insecticides to Singhi fish, Heteropneustes fossilis (Bloch). Dhaka Univ. Stud. Part B. 26: 115-122.

Konar, S.K. 1975. Pesticides and aquatic ecosystems. Indian J. Fish. 22(1-2): 80-85.

Mckim, J.M., Benoit, D.A., Biesinger, K.K., Brungs, W.A. and Siefert, R.E. 1975. Effects of pollution on fresh water fish. J. Water Pollut. Contr. Fed. 47: 1711-1764.

Meister, R.T. 1994. Farm chemicals handbook. Meister Publishing Co. Willoughby, OH., USA. pp. 145-148.

Mills, L.J. and Chichester, C. 2005. Review of evidence: Are endocrine-disrupting chemicals in the aquatic environment impacting fish populations. Sci. Total Envrion. 343(1-3): 1-34.

Moitra, S.K. and Sadhu, A.K. 1982. Effect of sublethal doses of phosphamidon on the alimentary system of the murrel Channa striatus (Bloch). J. Inland Fish Soc. 4(2): 5560.

Monir, M.S., Ashaf-Ud-Doulah, M., Rahman, M.K., Akhter, J.N. and Hossain, M.R. 2015. Effect of cypermethrin on the histoarchitecture of gills and liver of a freshwater catfish, Pangasianodon hypophthalmus. Asian J. Med. Biol. Res. 1(3): 641-64. https://doi.org/10.3329/ajmbr.v1i3.26488

Murty, A.S. 1986. Toxicity of pesticides to fish. CRC Press Inc., Boca Raton, F.L. P. 143.

Nannu, M.T.A. 2014. Effects of kinalux, an organophosphorus pesticide on the hematological parameters and some organs of nile tilapia (Oreochromis niloticus). MS Thesis, Department of Fisheries Biology and
Genetics, Bangladesh Agricultural University, Mymensingh, Bangladesh. P. 45.

Patyna, P.J., Davi, R.A., Parkerton, T.F., Brawn, R.P. and Cooper, K.R. 1999. A proposed multi-generation protocol for Japanese medaka (Oryzias latipes) to evaluate effects of endocrine disruptors. Sci. Total Environ. 233: 211-220. https://doi.org/10.1016/Soo489697(99)00227-2

Pimpao, C.T., Zampronio, A.R. and Silva de Assis, H.C. 2007. Effects of deltamethrin on hematological parameters and enzymatic activity in Ancistrus multispinis (Pisces, Teleostei). Pestic. Biochem. Physiol. 88: 122-127.

https://doi.org/10.1016/j.pestbp.2006.10.002

Rahman, M.Z., Hossain, Z., Mollah, M.F.A. and Ahmed, G.U. 2002. Effects of Diazinon 60 EC on Anabas testudineus, Channa punctatus and Barbodes gonionotus. NAGA-The ICLARM Quart. 25(2): 8-12.

Salam, M.A. 2014. Effects of Organophosphorous pesticide sumithion on hematological parameters and hepato-renal organs of common carp, Cyprinus carpio. MS Thesis, Department of Fisheries Management, Bangladesh Agricultural University, Mymensingh, Bangladesh. P. 75 .

Sharkar, C.C. 2016. Toxicity of agro-pesticide cypermethrin and its effects on histological changes of kidney in tengra (Mystus tengara). MS Thesis, Department of Fisheries Management, Bangladesh Agricultural University, Mymensingh, Bangladesh. P. 44.

Shastry, K.V. and Sharma, S.K. 1979. Endrin induced hepatic injury in Channa punctatus (Ham.). Indian J. Fish. 26(1\&2): 250-253.

Thomson, W.T. 1989. Agricultural Chemicals. Book I: Insecticides. Thomson Publications, Fresno, CA. P. 120.

Worthing, C.R. and Walker, S.B. (eds.). 1987. The pesticide manual. A world compendium. $8^{\text {th }}$ eds. British Crop Protection Council, Thornton Heath, UK. 67p. 